\title{
Exhaust Gas Recirculation on a Nano-Coated Combustion Chamber of a Diesel Engine Fueled with Waste Plastic Oil
}

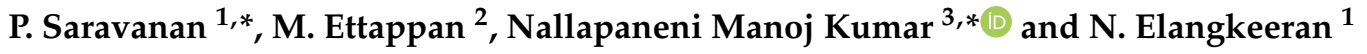 \\ 1 Department of Mechanical Engineering, Maliam Engineering College, Maliam 604304, Tamil Nadu, India; \\ 20mecedelangkeeran@mailamengg.com \\ 2 Department of Electrical and Electronics Engineering, Chennai Institute of Technology, \\ Chennai 600069, Tamil Nadu, India; ettappanm@citchennai.net \\ 3 School of Energy and Environment, City University of Hong Kong, Kowloon, Hong Kong \\ * Correspondence: saravananmech@mailamengg.com (P.S.); mnallapan2@cityu.edu.hk (N.M.K.)
}

Citation: Saravanan, P.; Ettappan, M.; Kumar, N.M.; Elangkeeran, N. Exhaust Gas Recirculation on a Nano-Coated Combustion Chamber of a Diesel Engine Fueled with Waste Plastic Oil. Sustainability 2022, 14, 1148. https://doi.org/10.3390/ su14031148

Academic Editor: Idiano D'Adamo

Received: 2 December 2021

Accepted: 18 January 2022

Published: 20 January 2022

Publisher's Note: MDPI stays neutral with regard to jurisdictional claims in published maps and institutional affiliations.

Copyright: (C) 2022 by the authors. Licensee MDPI, Basel, Switzerland. This article is an open access article distributed under the terms and conditions of the Creative Commons Attribution (CC BY) license (https:// creativecommons.org/licenses/by/ $4.0 /)$.

\begin{abstract}
Managing waste plastic is becoming a severe challenge. The industry and researchers have been looking at various opportunities in line with circular economy principles for effective plastic waste management. In that context, plastic waste valorization to oil as a substitute to fossil fuel has gained recent attention. In the literature, there exist few studies showing the use of oil derived from waste plastics in blends with other conventional fuels in compression ignition (CI) engines; however, studies on CI engines that use 100\% waste-derived fuels are limited. Additionally, the exhaust gas recirculation (EGR) concepts and the use of nano-coated chambers (like pistons, valves and cylinders heads) have been gaining interest purely from the engine performance enhancement perspective in recent years. Therefore, this study investigates engine performance by combining exhaust gas from the EGR technique and waste plastic oil (WPO) as inputs, followed by thermal coatings in the $\mathrm{CI}$ engine chambers for performance enhancement. The experimental setup of the engine is developed, and the engine's piston, valve and cylinder heads are coated with $\mathrm{Al}_{2} \mathrm{O}_{3}-\mathrm{SiO}_{4}$ material. The CI engine's energy, emission, and combustion characteristics are tested, followed by a scenario analysis compared with diesel-only fuel. The tested scenarios include a WPO $+\mathrm{Al}_{2} \mathrm{O}_{3}-\mathrm{SiO}_{4}$, $\mathrm{WPO}+\mathrm{Al}_{2} \mathrm{O}_{3}-\mathrm{SiO}_{4}+10 \% \mathrm{EGR}$, and $\mathrm{WPO}+\mathrm{Al}_{2} \mathrm{O}_{3}-\mathrm{SiO}_{4}+20 \%$ EGR. The results show that the piston crown's thermal coating increased the combustion performance. Significant impacts on the carbon monoxide, hydrocarbons, and smoke characteristics are observed for different \%EGR rates. The results also showed that the cooled EGR engine has decreased nitric oxide emissions. Overall, the results show that WPO combined with exhaust gas could be a potential fuel for future CI engines.
\end{abstract}

Keywords: waste plastic oil; plastic waste valorization; exhaust gas recirculation; nano-coated engine chambers; plastic oil combustion; $\mathrm{Al}_{2} \mathrm{O}_{3}-\mathrm{SiO}_{4}$ coating

\section{Introduction}

Among the various fuels, the demand for oil still exists in numerous sectors. As per the latest report by British Petroleum (BP), oil still holds the largest share of the planet's primary energy consumption, around $31.2 \%$, followed by coal and natural gas [1]. This domination has both positive and negative effects [2]. For instance, oil usage is reliable for primary energy consumption and can provide affordable energy security, which could be a positive effect [2,3]. However, this comes with a severe environmental threat to the planet in the form of greenhouse gas emissions (GHG), which is a negative effect [2]. On a global level, the GHG emissions due to oil consumption keep increasing. Based on Global Carbon Project data, the GHG emissions from oil consumption drastically increased from 1750 (i.e., 9.35 million $t$ ) to 2020 (i.e., 13.98 billion $t$ ) [4]. This approximately indicates a $+149,369 \%$ relative change between 1750 and 2020 [4]. Recently, many alternatives, including electricity from renewables and hydrogen, have evolved. Such alternatives are 
being considered widely across sectors to meet energy demands [5]. However, all these alternatives have started from a shallow base and still face significant challenges in coping with the ever-increasing energy demands. These challenges include the nonexistence of a systems approach, limited involvement of sustainable development goal 7 (SDG 7) considerations, lack of collaboration and dialogue throughout such a project's life cycle, and lack of social innovation and acceptability [6]. Additionally, the uncertainties associated with renewables make them difficult to adopt as a primary energy resource in various sectors [7]. As a result, many sectors are still dependent on liquid fuels. Taking the case of compression ignition (CI) engines and their applications, the demand for liquid fuels still exists and could continue even after 2040 [8]. Hence, from an environmental concerns point of view, it is no more a question of moving away from liquid fuels in the near future. Instead, it triggers questions related to exploring new and alternative liquid fuels (including biofuels and waste-derived fuels with lower environmental impacts), designing advancements of $\mathrm{CI}$ engines, ways to enhance engine performance, platforms and decision support systems that enable alternative fuel promotion [9-11].

In line with the raised questions, few studies exist in the literature; many have explored the use of alternative liquid fuels (including biofuels and waste-derived fuels) and exhaust gas recirculation (EGR) in CI engines [12-17]. Among the many waste-derived fuels, waste plastic oil (WPO) is one that is widely proposed for CI engines in literature even after witnessing net-zero energy options for industrial systems and high-valued waste-plastic derived porous carbons [18]. This is because of the need to attain equilibrium between the circularity of resources and consumers' needs, and it is a liquid fuel in this context. However, keeping such highly valued industrial applications in mind, industrial symbiosis or parallel processes of multi-commodity production systems can be developed. In such systems, a high-valued commodity can be used for carbon capture, and a low-valued commodity can be used for $\mathrm{CI}$ engines. On the other hand, few have worked on design aspects and thermal barrier coating (TBC) methods to enhance performance; among them, nano-coating materials are the most recently emerging [19-21]. First, biofuels in blends with conventional fuels are explored to minimize fuel usage and engine emissions [12,13]. However, many researchers have found a limitation with thermal efficiency [14-17]. Hence, the combined effect of high EGR and biofuel is considered to enhance thermal efficiency $[15,16]$. Therefore, with varying rates of EGR on a CI engine, the combustion, emission, and performance characteristics have been explored [15-17]. This combined approach noted that soot emissions are not monotonous with intermediate load $[15,16]$. However, the maximum soot emission is at intermediate EGR rates [17]. Hence, studies were conducted to research optimum fuel/hydrogen emissions from a varying air intake and EGR ratio. A heater with an on-off controller increases the intake air temperature in the gasoline engine performance and emissions field. This way, the cooled EGR reduces the $\mathrm{NO}_{x}$ emissions at the intake outlet, enabling high thermal efficiency. However, when the $\mathrm{CI}$ engines are tested with blends of waste-derived fuels (for instance, oil derived from waste plastics with diesel and ethanol) and EGR, the carbon monoxide (CO), hydrocarbon $(\mathrm{HC})$, oxides of nitrogen $\left(\mathrm{NO}_{\mathrm{x}}\right)$, and smoke emissions are observed to vary, suggesting the need to enhance the CI engine efficiency specific to the fuel type [22-24]. Mani et al. investigated the CI engine performance with the combined effect of $100 \%$ WPO and varying EGR rates [22]. They found that when the engine was operated with cooled EGR as an intake, the NOx emissions were reduced. The other emissions, such as $\mathrm{CO}$ and HC emissions, are slightly lower. The brake thermal efficiency is incomparable when the EGR rates are optimized at 20\% [22]. However, the observed smoke emissions of WPO seem high for all applied brake loads [22]. Another study on WPO as fuel in low heat rejection CI engines revealed that the performance, emission, and combustion characteristics are varied with varying injection timings [23]. Therefore, the TBC methods quoted in the literature are suggested to further enhance engine efficiency and lower emissions when 100\% WPO is used as a fuel in CI engines in combination with EGR [24]. 
In line with this, Saravanan et al. investigated the performance of a partially stabilized zirconia (PSZ)-coated, low-heat-rejection CI engine with WPO and found that PSZ enhances the engine efficiency [25]. Though several experimental studies exist on WPO use as an alternative fuel, studies on 100\% WPO with EGR and nano-coated CI engine chambers are not covered in the literature as per the author(s) knowledge [26-30]. Hence the use of WPO and EGR in line with the circular economy is proposed; see Figure 1. Hence, this study examines the exhaust gas circulation effect on a combustion chamber nano-coated with an $\mathrm{Al}_{2} \mathrm{O}_{3}-\mathrm{SiO}_{4}$-coated material.

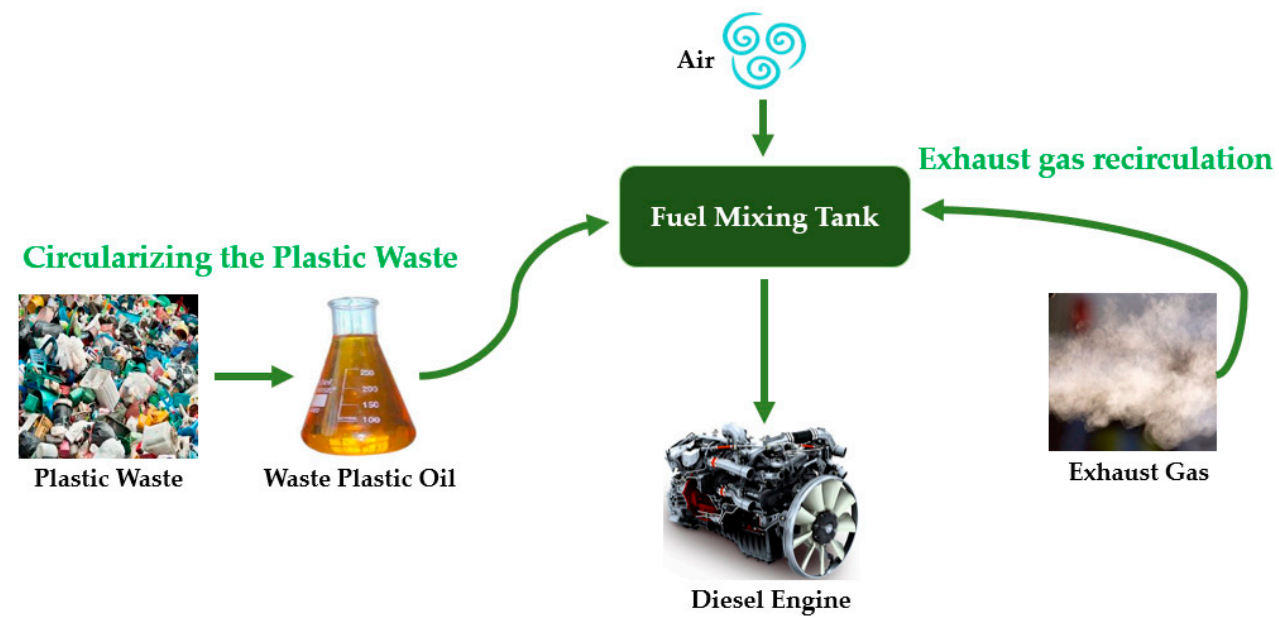

Figure 1. Use of waste plastic oil and exhaust gas recirculation in line with the circular economy.

The article is structured as follows. Section 2 is the materials and methods, where the details of WPO preparation, engine setup and experimental procedure are given. In Section 3, results are provided, along with a discussion and comparison with literature. Section 4 draws conclusions.

\section{Materials and Methods}

\subsection{Waste Plastic Oil Preparation}

WPO is the chemical product of the decomposition process of organic substances by heating. Waste plastic was processed and converted into oil through electrical pyrolysis. An electrical heater at 450 watts heats the plastics. The electrical heater consists of a resistance that adjusts the heating rate by varying the voltage controller. In the present work, the waste plastic was cut into several pieces and made into small chips. The plastic chips were washed, dried and fed into a reactor vessel made of borosilicate material with $2 \mathrm{~L}$ capacity. The plastic was treated in the reactor at a temperature of $400{ }^{\circ} \mathrm{C}$ without oxygen, which was monitored using a K-type thermocouple. This pyrolysis process can also be used to produce liquid fuel similar to diesel. The pyrolysis products in the form of vapour were sent to a water-cooled condenser. The condensed liquid was collected as fuel. A double-tube condenser was installed at the outlet of the reactor to separate the gas and oil products. Water, at room temperature, was circulated around the condenser at a constant rate. After condensation, the gases were converted into liquid fuel and collected in the collection tank at the bottom. The schematic diagram of the pyrolysis process of waste plastics is shown in Figure 2. 


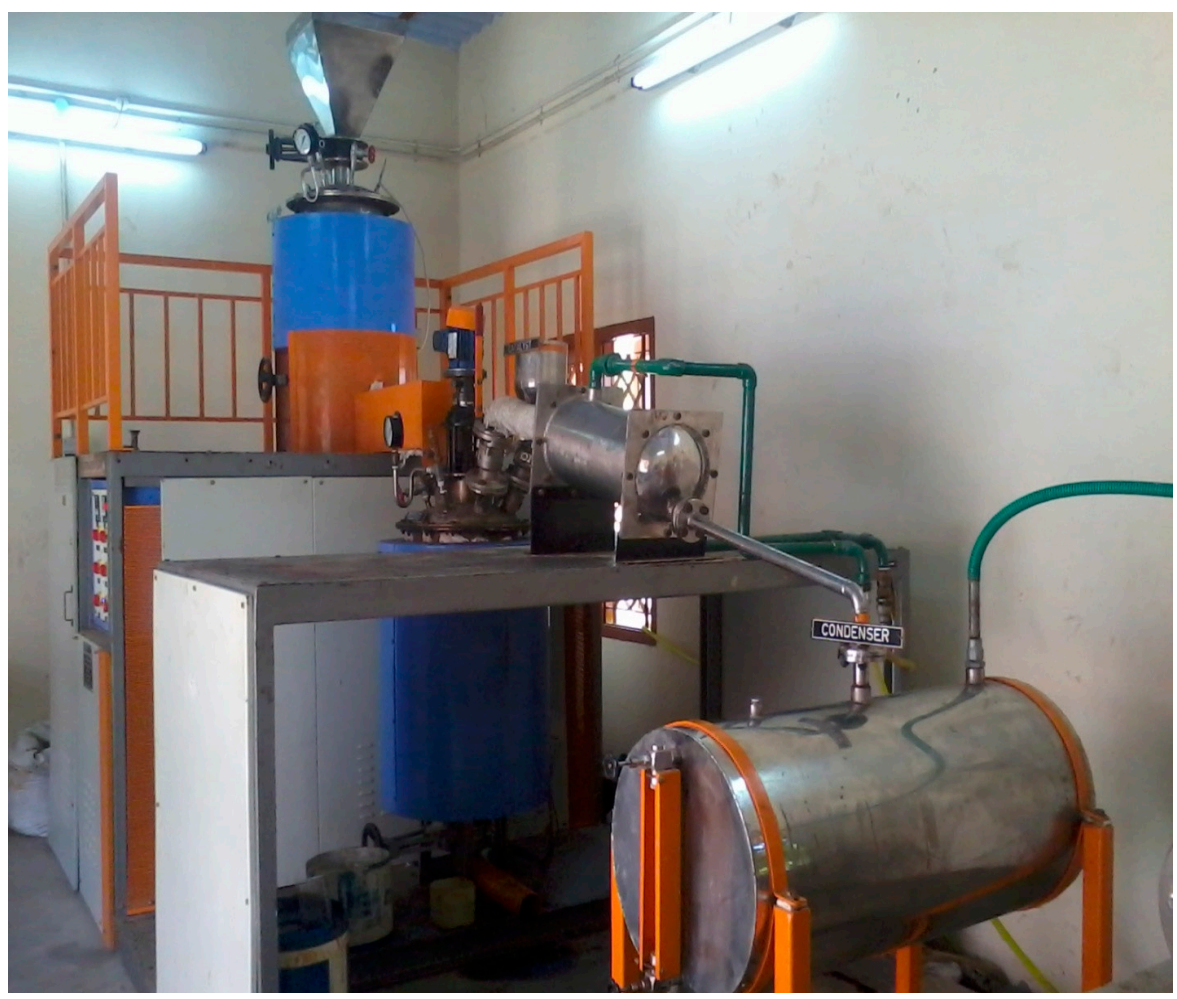

Figure 2. The experimental model of the pyrolysis process of waste plastics.

The non-condensable gases were let out into the atmosphere. The WPO collected was crude in nature. For $1 \mathrm{~kg}$ of WPO, about $2.09 \mathrm{~kg}$ of plastic waste feedstock was required. The product yields from the process are WPO (50\%), Pyro gas (40\%) and char (10\%). The heat energy required to convert the waste plastic into the products was around $7.8 \mathrm{MJ} / \mathrm{kg}$. The residence time of the pyrolysis process was $90 \mathrm{~min}$. The composition of WPO reconfirms and is comparable with the values available in the early research works. Since the oil collected for this study was untreated, the WPO contains impurities, dust, and low and high volatile fractions of hydrocarbons. WPO was filtered by fabric filter and again filtered by micron filter. The efficiency of the filtration is $99 \%$.

\subsection{Properties and Elemental Analysis}

The analysis of the WPO was done to compare the thermophysical properties and elemental composition of WPO with the standard diesel fuel; see Table 1. When compared to diesel, the specific gravity and calorific value of WPO were reduced by about $0.595 \%$ and $4.73 \%$, respectively. WPO has a higher kinematic viscosity than diesel, providing more resistance to flow in the winter. The sulfur and ash content is $6.95 \%$ and $3.76 \%$, respectively, for WPO; hence, there is a possibility of lower emissions. The WPO's flash and fire points are observed to be more or less similar to diesel. WPO has lower carbon (C) elements when compared to diesel fuel. However, the other elements such as hydrogen $(\mathrm{H})$, oxygen $(\mathrm{O})$, and nitrogen $(\mathrm{N})$ are higher for WPO. The sulfur $(\mathrm{S})$ elements are zero in WPO, whereas in diesel, it is around 0.359 . 
Table 1. Properties and the elemental analysis of WPO and diesel.

\begin{tabular}{|c|c|c|c|c|}
\hline \multirow{2}{*}{ Analysis } & & \multirow{2}{*}{ Units } & \multicolumn{2}{|c|}{ Fuel Types } \\
\hline & & & WPO & Diesel \\
\hline \multirow{7}{*}{$\begin{array}{c}\text { Thermophysical } \\
\text { properties }\end{array}$} & Specific gravity & - & 0.835 & 0.840 \\
\hline & Calorific value & $\mathrm{kJ} / \mathrm{kg}$ & $4.43 \times 10^{3}$ & $4.65 \times 10^{3}$ \\
\hline & Kinematic viscosity & cSt at $40^{\circ} \mathrm{C}$ & 2.52 & 2 \\
\hline & Flash point & ${ }^{\circ} \mathrm{C}$ & 42 & 50 \\
\hline & Fire point & ${ }^{\circ} \mathrm{C}$ & 45 & 56 \\
\hline & Sulfur content & $\%$ & 0.034 & 0.046 \\
\hline & Ash content & $\%$ & 0.00023 & 0.043 \\
\hline \multirow{5}{*}{ Elemental analysis } & C & $\%$ & 74.36 & 86.03 \\
\hline & $\mathrm{H}$ & $\%$ & 14.31 & 13.36 \\
\hline & $\mathrm{O}$ & $\%$ & 11.28 & 0 \\
\hline & $\mathrm{N}$ & $\%$ & 0.395 & 0.251 \\
\hline & $S$ & $\%$ & 0 & 0.359 \\
\hline
\end{tabular}

\subsection{Nano-Coated Combustion Chamber of Diesel Engine}

The plasma spraying method primarily sprays molten material or thermal softening on a surface to provide a layer. The physical and chemical characteristics of imprudent ceramic powder $\mathrm{Al}_{2} \mathrm{O}_{3}-\mathrm{SiO}_{4}$ combined with wear resistance, low friction coefficients, higher ionic conductivity, high hardness and low thermal conductance can make better engineering materials; see Table 2.

Table 2. Properties of $\mathrm{Al}_{2} \mathrm{O}_{3}-\mathrm{SiO}_{4}$ coating.

\begin{tabular}{cc}
\hline Property & $\mathbf{A l}_{\mathbf{2}} \mathbf{O}_{\mathbf{3}}-\mathbf{S i O}_{\mathbf{4}}$ \\
\hline Density $\left(\mathrm{g} \cdot \mathrm{cm}^{-3}\right)$ & 3.6 \\
Modulus of Rupture (MPa) & 348 \\
Hardness-Knoop (GPa) & - \\
Specific Heat $(\mathrm{J} / \mathrm{kgK})$ & 437 \\
Young's Modulus $(\mathrm{GPa})$ & 23 \\
Thermal Conductivity $(\mathrm{W} / \mathrm{mK})$ & $2-5$ \\
Poisson Ratio & 0.20 \\
\hline
\end{tabular}

The feed machine injects the cover material with a carrier gas in powder form. These particles melt and adhere as a coating onto the processed foundation material. The piston, cylinders and valves in use with the $\mathrm{Al}_{2} \mathrm{O}_{3}-\mathrm{SiO}_{4}$ engine are shown in Figure 3.
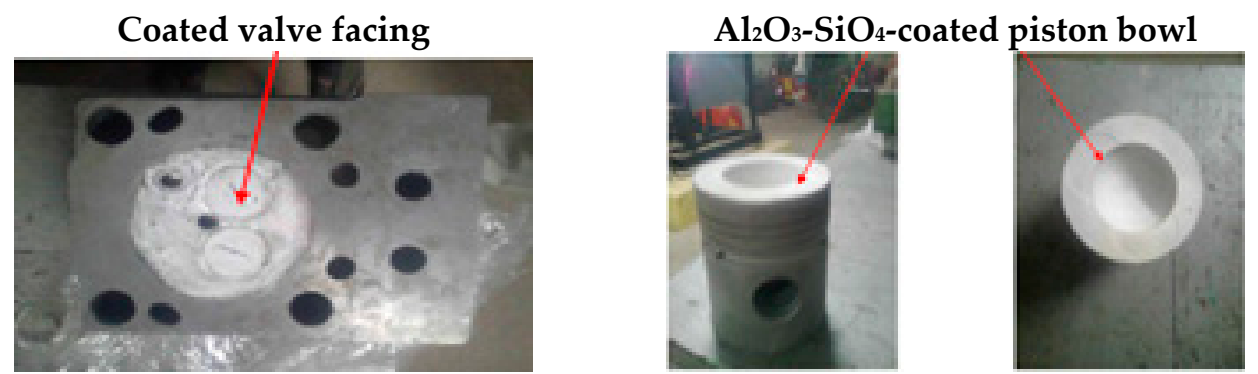

Figure 3. $\mathrm{Al}_{2} \mathrm{O}_{3}-\mathrm{SiO}_{4}$-coated piston, cylinder head and valves.

\subsection{Experimental Testing}

The experimental setup is shown in Figure 4. It consists of a 4-stroke cylinder, constant speed, water-cooled, 16.5:1 compression ignition engine, and a generator loaded with variable power. The engine is rated at 200 bar with static injection timing of $23^{\circ} \mathrm{BTDC}$. Before the engine started, a check was made of the stock inside the fuel tank, cooling water flow, and lubricant oil in the oil sump. The engine was started and heated. At rated speed, 
the engine speed is preserved-current and voltage measurements are used for the facility developed by the engine.

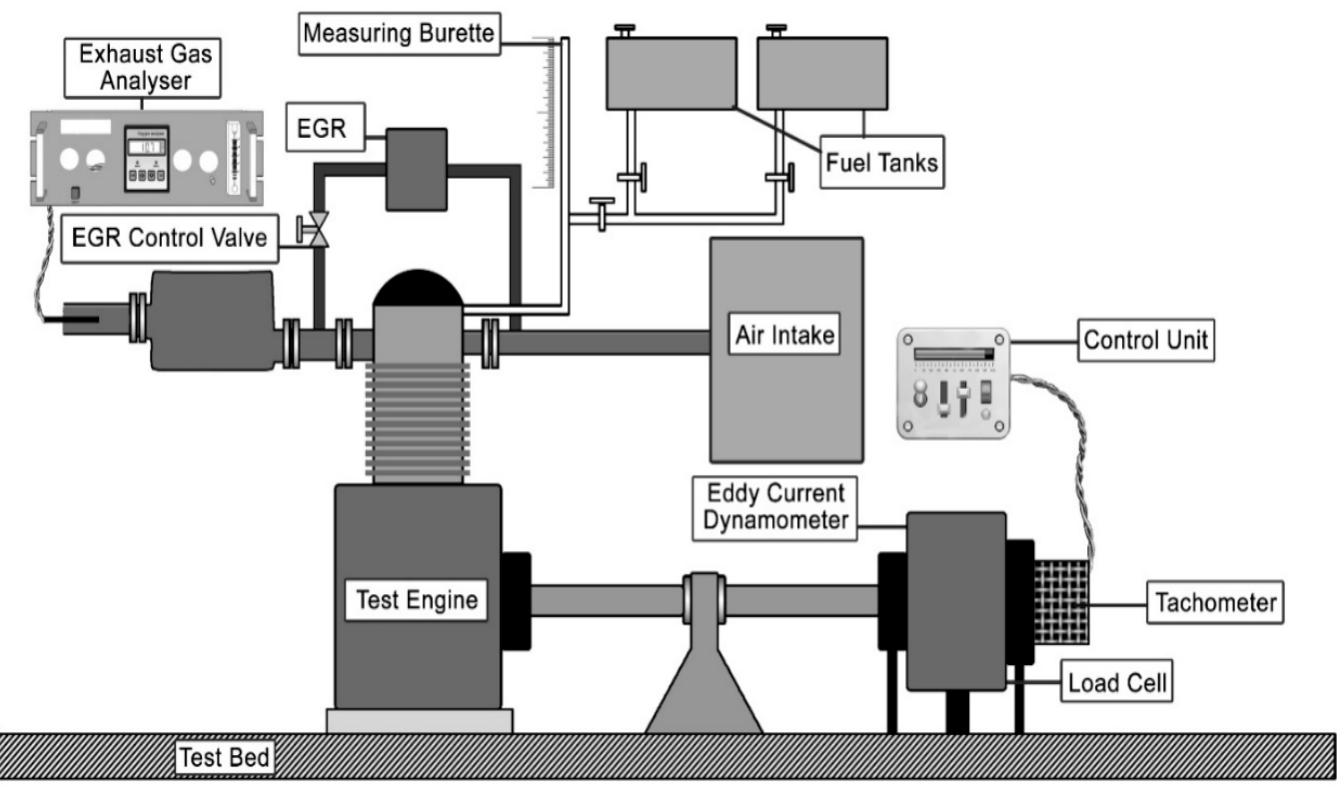

Figure 4. Schematic representation of test engine setup used for the experiment.

The visual temperature indicator thermocouple was not appropriate for calculating the cooling temperature of the water. A piezoelectric pressure sensor was used to measure the cylinder pressure. QROTECH's exhaust gas analyzer measured $\mathrm{CO}, \mathrm{NO}_{\mathrm{x}}$ and $\mathrm{HC}$. For different loads, the experiments have been repeated without maximum load.

\section{Results and Discussion}

The experimental results include the diesel engine's performance with 3 different fuel scenar$\operatorname{ios}\left(\mathrm{WPO}+\mathrm{Al}_{2} \mathrm{O}_{3}-\mathrm{SiO}_{4}, \mathrm{WPO}+\mathrm{Al}_{2} \mathrm{O}_{3}-\mathrm{SiO}_{4}+10 \% \mathrm{EGR}\right.$, and $\left.\mathrm{WPO}+\mathrm{Al}_{2} \mathrm{O}_{3}-\mathrm{SiO}_{4}+20 \% \mathrm{EGR}\right)$ compared with the standard diesel fuel. Three types of analysis, namely energy, emissions, and combustion, are carried out for each fuel scenario. As shown in Figure 5, multiple characteristics are observed for each fuel scenario under these three analyses.

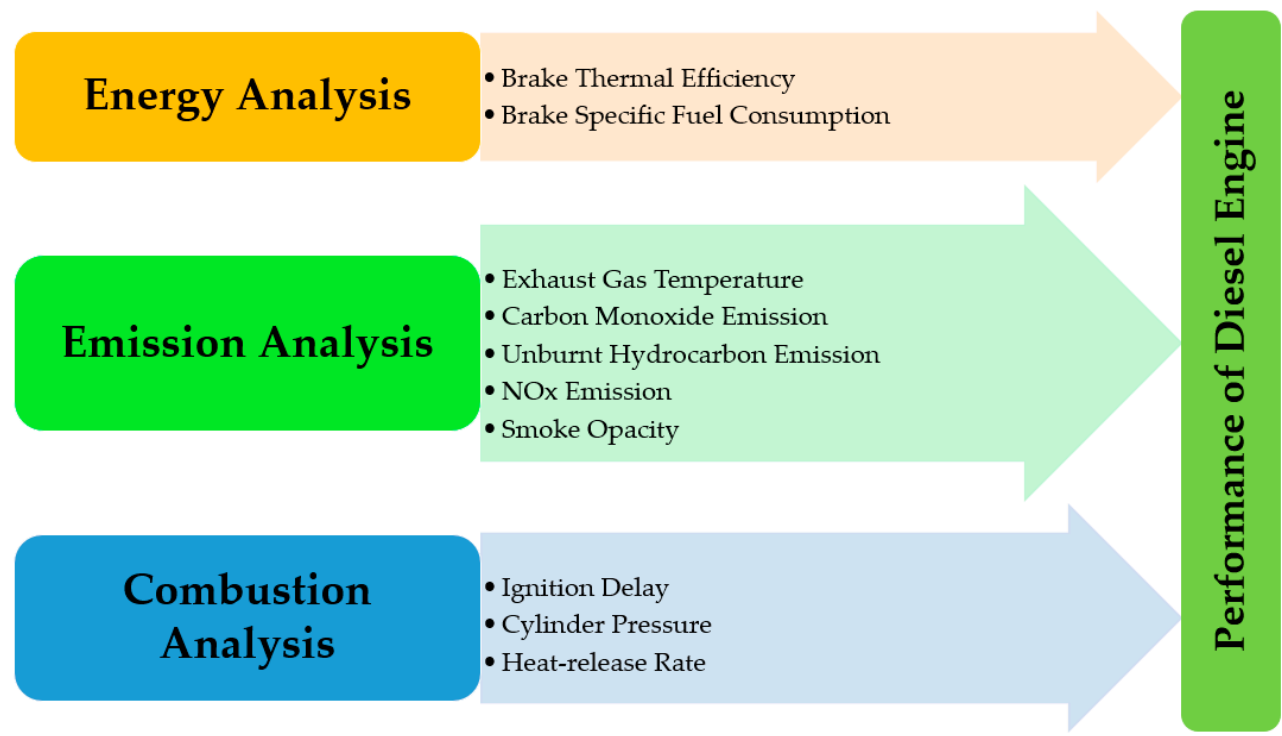

Figure 5. Energy, emission and combustion characteristics that reveal diesel engine performance. 


\subsection{Brake Thermal Efficiency (BTE)}

The BTE results observed for the investigated CI engine under four different fuel use scenarios are presented in Figure 6. The BTE of the CI engine is a characteristic that measures fuel efficiency under different loads. Generally, engines that are claimed to be fuel-efficient will have higher BTE; this means lower fuel consumption [26].

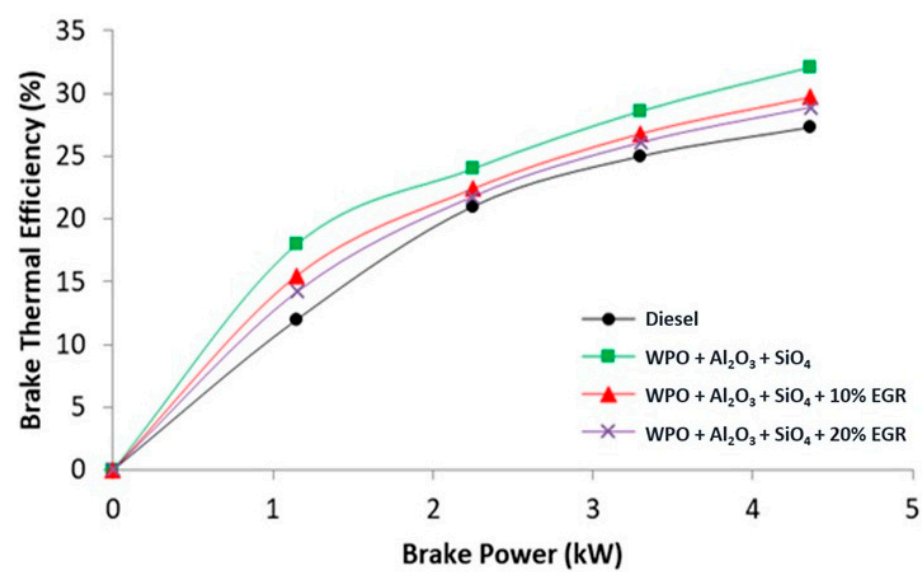

Figure 6. Variations of brake thermal efficiency with brake power.

The results presented in Figure 6 showed a noticeable difference in BTE for diesel fuel, $\mathrm{WPO}+\mathrm{Al}_{2} \mathrm{O}_{3}-\mathrm{SiO}_{4}$ and $\mathrm{WPO}+\mathrm{Al}_{2} \mathrm{O}_{3}-\mathrm{SiO}_{4}$ with EGR. It was found that the $\mathrm{CI}$ engine whose combustion chambers are coated with $\mathrm{Al}_{2} \mathrm{O}_{3}-\mathrm{SiO}_{4}$ and fueled with WPO and blends of WPO and EGR has a higher BTE than that of an engine fueled with diesel. The observed improvement in $\mathrm{BTE}$ of a $\mathrm{CI}$ engine for $\mathrm{WPO}+\mathrm{Al}_{2} \mathrm{O}_{3}-\mathrm{SiO}_{4}$ over diesel is approximately $29.6 \%$. A similar trend in BTE has been observed even with the increased brake powers $[26,27]$. Though EGR in CI engines is said to enhance thermal efficiency, it becomes less efficient in this case, as the observed BTE for blends of WPO and EGR is lower when compared to the WPO. Overall, the BTE results suggest that the CI engine with $\mathrm{WPO}+\mathrm{Al}_{2} \mathrm{O}_{3}-\mathrm{SiO}_{4}$ is fuel-efficient.

\subsection{Brake-Specific Energy Consumption (BSEC)}

Figure 7 shows the BSEC results of the CI engine under four different fuel use scenarios. BSEC measures the fuel efficiency of an engine that burns fuel and produces shaft power. It is simply the rate of fuel consumption by the CI engine divided by the power produced. The results presented in Figure 7 showed a noticeable difference in BSEC for diesel fuel, $\mathrm{WPO}+\mathrm{Al}_{2} \mathrm{O}_{3}-\mathrm{SiO}_{4}$ and $\mathrm{WPO}+\mathrm{Al}_{2} \mathrm{O}_{3}-\mathrm{SiO}_{4}$ with EGR. It was found that the $\mathrm{CI}$ engine whose combustion chambers are coated with $\mathrm{Al}_{2} \mathrm{O}_{3}-\mathrm{SiO}_{4}$ and fueled with blends of WPO and EGR has a higher BSEC than that of an engine fueled with WPO and diesel. The observed BSEC at the maximum load condition of the $\mathrm{Al}_{2} \mathrm{O}_{3}-\mathrm{SiO}_{4}$ coated engine fueled with WPO is $10.43 \mathrm{MJ} / \mathrm{kW}-\mathrm{h}$, almost the same as the diesel fuel. The BSEC for the same engine with 10 and 20\% EGR rates is $11.76 \mathrm{MJ} / \mathrm{kW}-\mathrm{h}$ and $11.04 \mathrm{MJ} / \mathrm{kW}-\mathrm{h}$, respectively. The decrease in BSEC with EGR is due to the rise in the intake charge temperature, which increases the fuel burning rate [28].

Additionally, the relationship between BSEC and brake power under different fuel use scenarios suggests that the difference in BSEC is high for lower brake power, i.e., from $1 \mathrm{~kW}$ to $3 \mathrm{~kW}$. As brake power tends to increase above $3 \mathrm{~kW}$, the difference in BSEC seems to be very small for the same fuel use scenarios. Overall, the CI engines' BSEC decreased with an increase in brake power for all the four fuel use scenarios, suggesting that WPO is a suitable fuel. 


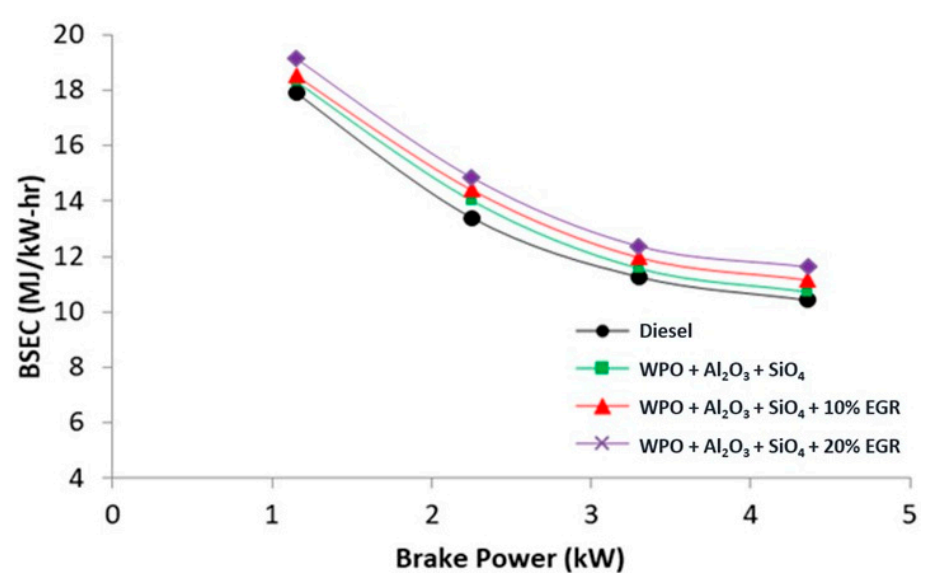

Figure 7. Variations of brake-specific energy consumption with brake power.

\subsection{Exhaust Gas Temperature (EGT)}

The EGT typically refers to the temperature of the exhaust gases discharged from the CI engine. From this investigation, we observed the EGT results of the CI engine under different fuel use scenarios; see Figure 8. In all the fuel use scenarios, the EGT increased with the engine load; however, there was a noticeable difference in EGT for diesel fuel, $\mathrm{WPO}+\mathrm{Al}_{2} \mathrm{O}_{3}-\mathrm{SiO}_{4}$ and $\mathrm{WPO}+\mathrm{Al}_{2} \mathrm{O}_{3}-\mathrm{SiO}_{4}$ with EGR. It is also found that the CI engine whose combustion chambers are coated with $\mathrm{Al}_{2} \mathrm{O}_{3}-\mathrm{SiO}_{4}$ and fueled with WPO and blends of WPO and EGR has a higher EGT than that of an engine fueled with diesel. Additionally, the EGT of WPO is higher than blends of WPO and EGR. For instance, the observed EGT in the $\mathrm{WPO}+\mathrm{Al}_{2} \mathrm{O}_{3}-\mathrm{SiO}_{4}$ fuel scenario at the highest brake power was $6.4 \%$ and $12 \%$ higher than EGR rates $10 \%$ and $20 \%$, respectively. The decrease in EGT in the case of EGR is possibly due to a smooth process leading to a lower burning temperature [28]. Besides, the exhaust gas's specific heat is higher than the air intake [29].

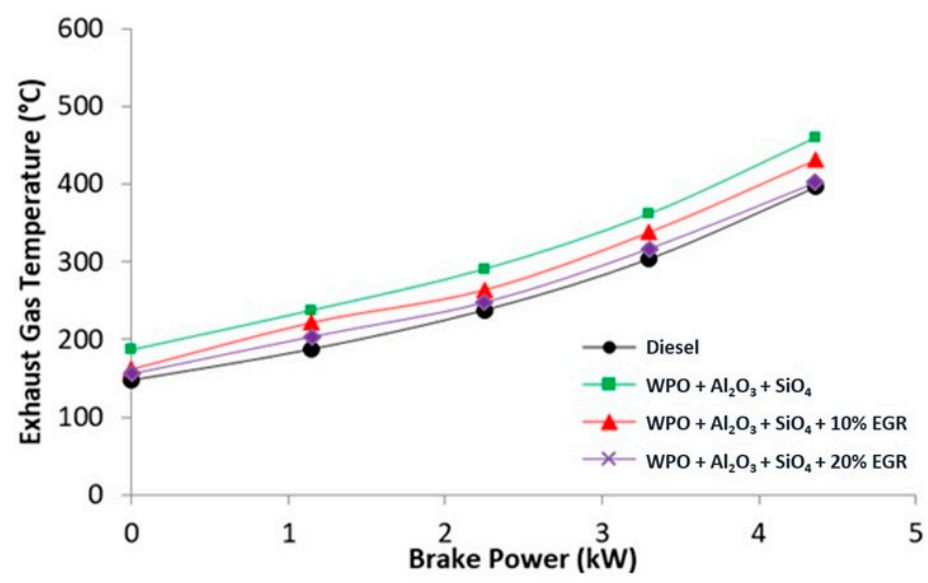

Figure 8. Variation of exhaust gas temperature with brake power.

\subsection{Carbon Monoxide (CO) Emissions}

$\mathrm{CO}$ is one of the regulated emissions released from $\mathrm{CI}$ engines, and its release usually is low. However, they can be significantly higher at brake power, and the same is observed in this investigation; see Figure 9. 


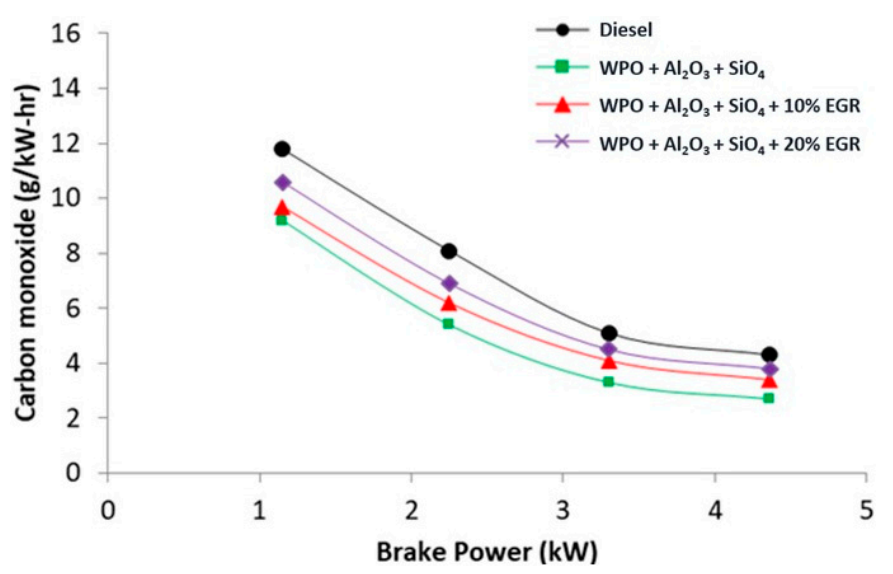

Figure 9. Variation of carbon monoxide emissions with brake power.

The results presented in Figure 9 show a noticeable difference in $\mathrm{CO}$ emissions released from $\mathrm{CI}$ engines for diesel fuel, $\mathrm{WPO}+\mathrm{Al}_{2} \mathrm{O}_{3}-\mathrm{SiO}_{4}$ and $\mathrm{WPO}+\mathrm{Al}_{2} \mathrm{O}_{3}-\mathrm{SiO}_{4}$ with EGR. It is found that the $\mathrm{CI}$ engine whose combustion chambers are coated with $\mathrm{Al}_{2} \mathrm{O}_{3}-\mathrm{SiO}_{4}$ and fueled with WPO and blends of WPO and EGR has lower CO emissions compared to diesel. Additionally, the $\mathrm{CO}$ emission for the WPO case is observed to be much lower compared to blends of WPO and EGR. For instance, the observed $\mathrm{CO}$ in the WPO $+\mathrm{Al}_{2} \mathrm{O}_{3}-\mathrm{SiO}_{4}$ fuel scenario at the highest brake power was $2.8 \mathrm{~g} / \mathrm{kW}$-h. In contrast, in the case of $10 \%$ and $20 \%$ EGR, it is $3.5 \mathrm{~g} / \mathrm{kW}-\mathrm{h}$ and $3.9 \mathrm{~g} / \mathrm{kW}$-h, respectively. With increasing EGR concentrations, $\mathrm{CO}$ emissions are rising due to oxygen concentration in the air-fuel mixtures in different sections in the combustion chamber [27]. Additionally, this heterogeneous blend does not entirely combust and results in CO emissions [26,29].

\subsection{Unburnt Hydrocarbon (UHC) Emissions}

The hydrocarbon emissions emitted from CI engines for various reasons of incomplete combustion can be called UHC emissions. They typically occur because some regions of the combustion chamber may have a feeble flame, which results in low combustion temperatures. In Figure 11, the UHC results of the CI engine under four different fuel use scenarios are presented. In all four scenarios, a noticeable difference in released UHC is observed, where diesel records a high amount of emissions followed by $\mathrm{WPO}+\mathrm{Al}_{2} \mathrm{O}_{3}-\mathrm{SiO}_{4}+20 \% \mathrm{EGR}, \mathrm{WPO}+\mathrm{Al}_{2} \mathrm{O}_{3}-\mathrm{SiO}_{4}+10 \% \mathrm{EGR}$, and $\mathrm{WPO}+\mathrm{Al}_{2} \mathrm{O}_{3}-\mathrm{SiO}_{4}$. For instance, the observed $\mathrm{CO}$ in the $\mathrm{WPO}+\mathrm{Al}_{2} \mathrm{O}_{3}-\mathrm{SiO}_{4}$ fuel scenario at the highest brake power was $0.44 \mathrm{~g} / \mathrm{kW}-\mathrm{h}$. In contrast, in the case of $10 \%$ and $20 \% \mathrm{EGR}$, it is $0.46 \mathrm{~g} / \mathrm{kW}$-h and $0.49 \mathrm{~g} / \mathrm{kW}-\mathrm{h}$, respectively. With increasing EGR concentrations, UHC emissions rise due to low oxygen concentrations in the air-fuel mixtures in different sections in the combustion chamber [29].

\section{6. $\mathrm{NO}_{x}$ Emissions}

$\mathrm{NO}_{x}$ is one of the regulated emissions released from the $\mathrm{CI}$ engines and is considered a highly active ozone precursor. Therefore, to reduce the $\mathrm{NO}_{x}$ emissions, the engine's combustion temperature must be lowered, typically by injecting EGR. Additionally, depending upon the fuel used, the $\mathrm{NO}_{\mathrm{x}}$ emissions vary. In Figure 10, the results for four different fuel usage scenarios are shown. In all four scenarios, a noticeable difference in released $\mathrm{NO}_{\mathrm{x}}$ emissions is observed, where WPO records a high amount of emissions followed by $\mathrm{WPO}+\mathrm{Al}_{2} \mathrm{O}_{3}-\mathrm{SiO}_{4}+10 \% \mathrm{EGR}, \mathrm{WPO}+\mathrm{Al}_{2} \mathrm{O}_{3}-\mathrm{SiO}_{4}+20 \% \mathrm{EGR}$, and $\mathrm{WPO}+\mathrm{Al}_{2} \mathrm{O}_{3}-\mathrm{SiO}_{4}$. For instance, the observed $\mathrm{NO}_{x}$ in the $\mathrm{WPO}+\mathrm{Al}_{2} \mathrm{O}_{3}-\mathrm{SiO}_{4}$ fuel scenario at the highest brake power was $9.7 \mathrm{~g} / \mathrm{kW}-\mathrm{h}$. In contrast, in the case of $10 \%$ and $20 \% \mathrm{EGR}$, it is $9.5 \mathrm{~g} / \mathrm{kW}$-h and $8.4 \mathrm{~g} / \mathrm{kW}$-h, respectively. As stated earlier, the $\mathrm{NO}_{\mathrm{x}}$ emissions decreased with an increase in EGR levels for all load conditions $[17,25]$. Overall, the reduced oxygen content and fire temperatures in a combustible mixture are the potential reasons for reducing $\mathrm{NO}_{\mathrm{x}}$ emissions in the EGR case. 


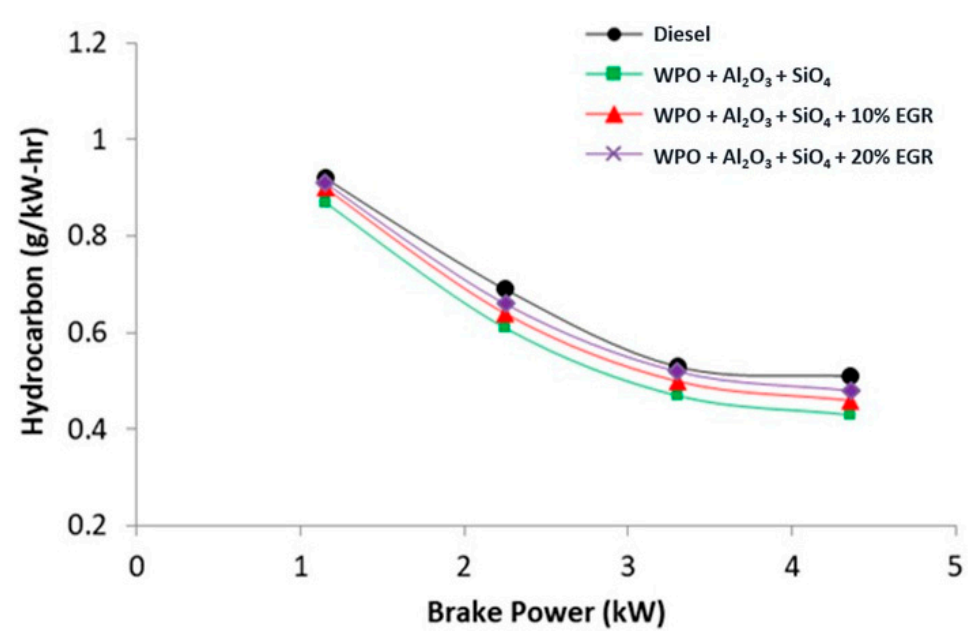

Figure 10. Variation of hydrocarbons with brake power.

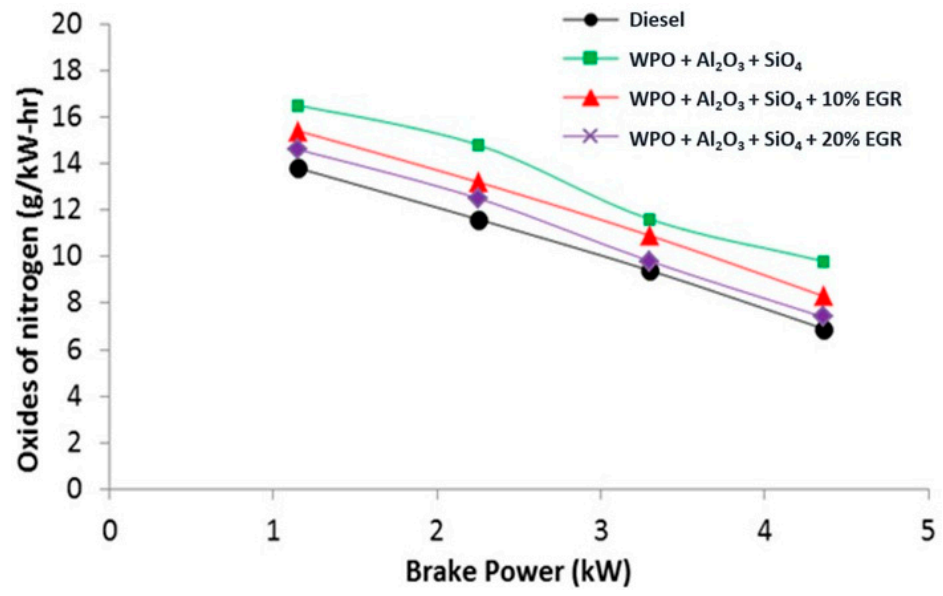

Figure 11. Variations of oxides of nitrogen with brake power.

\subsection{Smoke Opacity}

The smoke opacity represents the visible black smoke in the CI engine exhaust. In Figure 12, the smoke opacity results for four different fuel usage scenarios are shown. In all four scenarios, a noticeable difference in smoke emissions is observed, where $\mathrm{WPO}+\mathrm{Al}_{2} \mathrm{O}_{3}-\mathrm{SiO}_{4}+20 \% \mathrm{EGR}$ records a high amount of emissions, followed by $\mathrm{WPO}+\mathrm{Al}_{2} \mathrm{O}_{3}-\mathrm{SiO}_{4}+10 \% \mathrm{EGR}, \mathrm{WPO}+\mathrm{Al}_{2} \mathrm{O}_{3}-\mathrm{SiO}_{4}$ and diesel. For instance, the observed smoke emission in the $\mathrm{WPO}+\mathrm{Al}_{2} \mathrm{O}_{3}-\mathrm{SiO}_{4}$ fuel scenario at the highest brake power was 5.2 BSU. In contrast, in the case of $10 \%$ and $20 \%$ EGR, it is 5.4 BSU and 5.8 BSU, respectively. From this observation, it can be understood that the smoke emissions would increase with increasing EGR concentrations. This is because the recirculation of exhaust gas reduces oxygen availability for fuel combustion, leading to incomplete combustion and increased particulate matter formation [29]. 


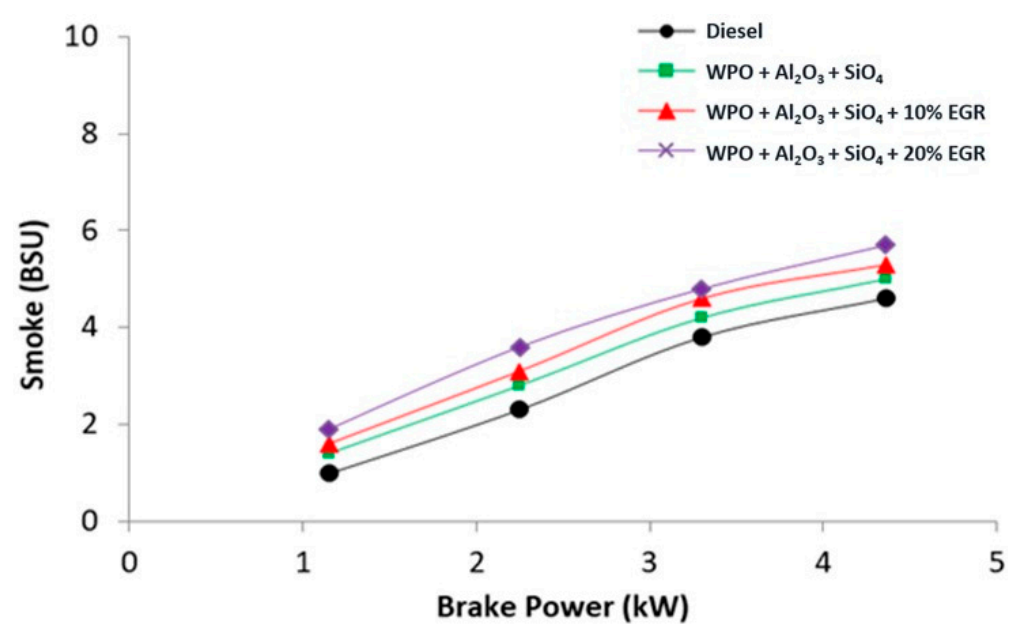

Figure 12. Variations of smoke with brake power.

\subsection{Ignition Delay}

Ignition delay is a crucial parameter in the $\mathrm{CI}$ engine, typically referring to the time from spark initiation to $10 \%$ of the fuel burning. In Figure 13, the ignition delay results of the $\mathrm{CI}$ engine under four different fuel use scenarios are given.

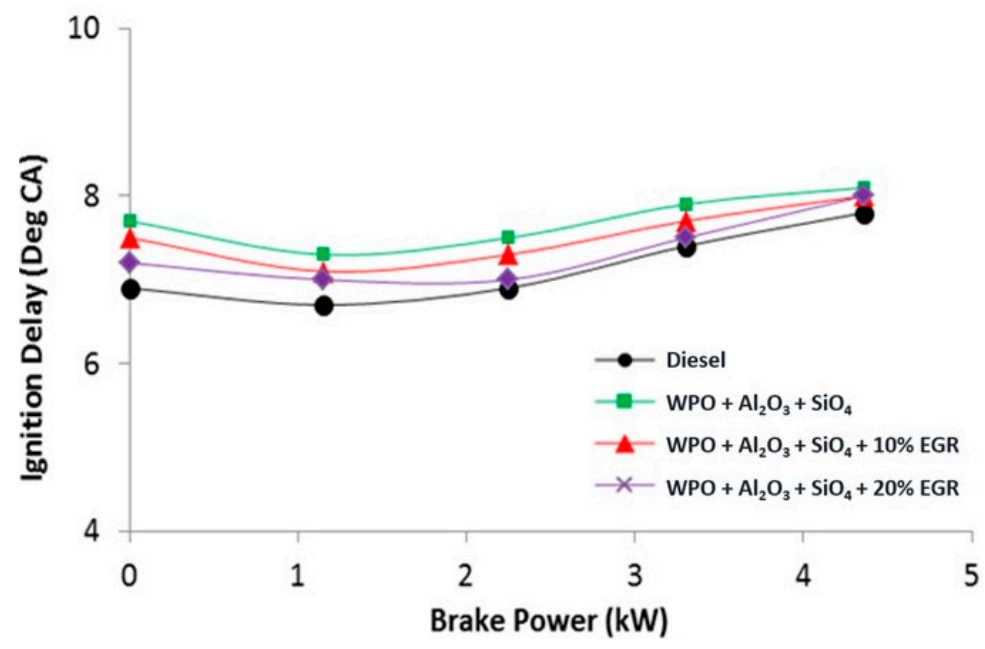

Figure 13. Variation of ignition delay with brake power.

The observed results are significantly affected by the applied brake power load. For instance, in all four fuel use scenarios, the ignition delay is lower at full load and higher at no load. The increase in fuel vaporization resulting from higher cylinder temperatures at full brake force decreased the chemical delay and resulted in reduced ignition delay. However, when the fuel use scenarios are compared, at no load and a full load, the CI engine whose combustion chambers are coated with $\mathrm{Al}_{2} \mathrm{O}_{3}-\mathrm{SiO}_{4}$ and fueled with WPO have higher ignition delay, followed by the blends of WPO and EGR $[17,25]$. The ignition delay for diesel fuel is observed to be lower among all the fuel use scenarios.

\subsection{Cylinder Pressure}

The cylinder pressure results for the $\mathrm{CI}$ engine under four different fuel use scenarios are presented in Figure 14. Only a noticeable difference is observed for different crank angles. The $\mathrm{CI}$ engine whose combustion chambers are coated with $\mathrm{Al}_{2} \mathrm{O}_{3}-\mathrm{SiO}_{4}$ and fueled with WPO have high cylinder pressure, followed by the blends of WPO with $10 \%$ and $20 \%$ EGR. For instance, a high pressure of 68.7 bar at $10{ }^{\circ} \mathrm{CA}$ is observed for $\mathrm{WPO}+\mathrm{Al}_{2} \mathrm{O}_{3}-\mathrm{SiO}_{4}$, which is around $2.7 \%$ and $5.4 \%$ higher than the maximum pressure of the same engine with 10 and 20\% EGR. Therefore, it can be understood that, with the EGR, the peak pressure can 
significantly decrease. This is because the use of EGR raises the consumption charge and the basic thermal potential; it also decreases the supply of oxygen, leading to an adverse impact on the combustion rates, thus resulting in reduced peak cylinder values $[17,25]$.

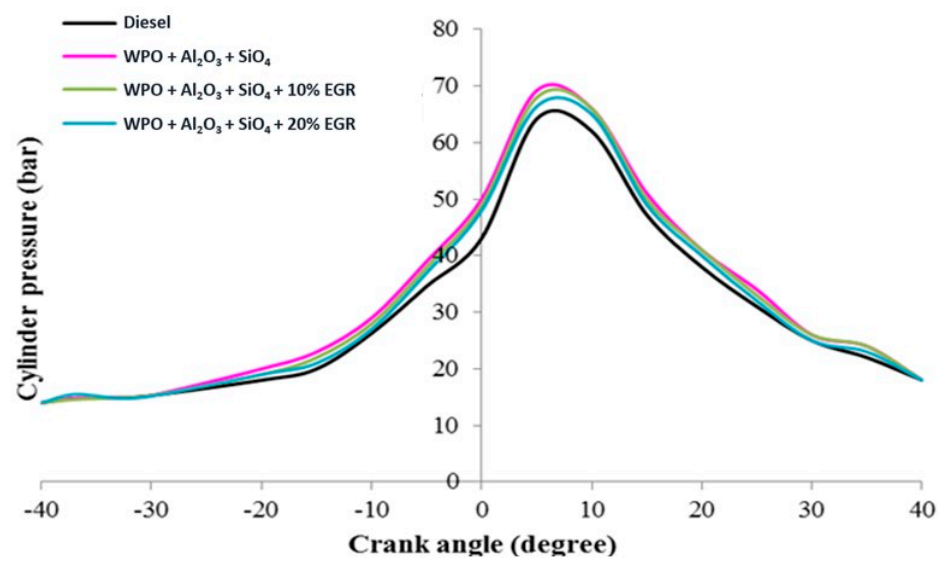

Figure 14. Variation of cylinder pressure with crank angle.

\subsection{Heat-Release Rate}

The heat generation rate in the CI engine is typically measured with a heat-release rate indicator. The observed inconsistency of the heat-release rate of the CI engine under four different fuel use scenarios is shown in Figure 15. The CI engine whose combustion chambers are coated with $\mathrm{Al}_{2} \mathrm{O}_{3}-\mathrm{SiO}_{4}$ and fueled with WPO is observed to operate with a maximum heat-release rate of $97 \mathrm{~J} /{ }^{\circ} \mathrm{CA}$, which is around $7.32 \%$ and $3.2 \%$ higher when compared with 10 and 20\% EGR. This is in line with the standard property of EGR, where the addition of exhaust gas usually decreases the fuel heat release activity due to burned gases, thus resulting in a lower heat release rate $[25,30]$.

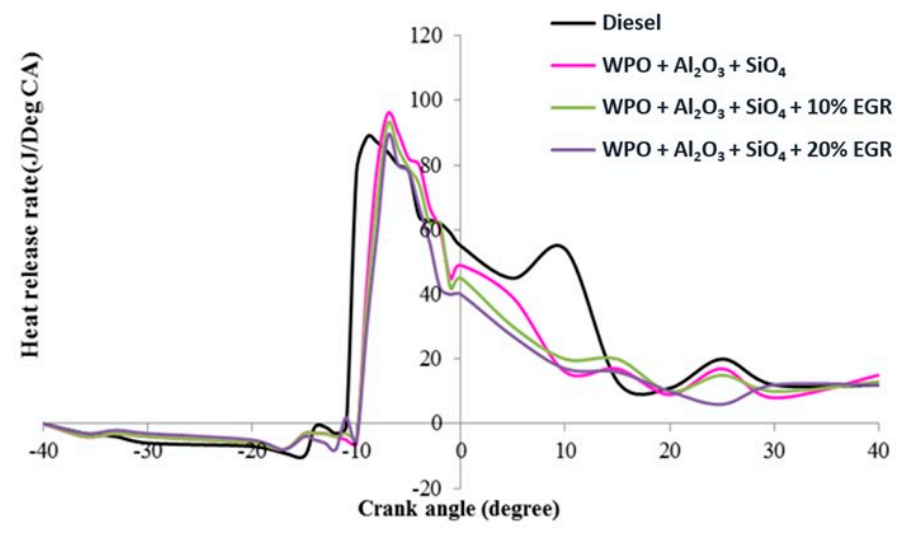

Figure 15. Variation of the heat release rate with crank angle.

\subsection{Comparison with WPO and Other Fuels in Available Literature}

The performance results of this investigation are compared with the existing literature considering studies that used the same fuel, different fuels, nano-coating materials, and the standard fuel, i.e., diesel. For each referred literature, see Tables 3 and 4; the energy, emission, and combustion characteristics that we discussed in Sections 3.1-3.11 are considered. The comparative results from Table 3 with WPO fuel shows that the observed $\mathrm{BTE}$ is more or less comparable in $\mathrm{WPO}+\mathrm{Al}_{2} \mathrm{O}_{3}-\mathrm{SiO}_{4}$ and $\mathrm{WPO}+\mathrm{Al}_{2} \mathrm{O}_{3}-\mathrm{SiO}_{4}+10 \%$ EGR However, the $\mathrm{WPO}+\mathrm{Al}_{2} \mathrm{O}_{3}-\mathrm{SiO}_{4}+20 \%$ EGR case showed better BTE. The BSFC parameter is observed to be high when compared to literature results. The observed emissions are much lower when compared to the literature results. 
Table 3. Comparison of the results with existing literature works on WPO.

\begin{tabular}{|c|c|c|c|c|c|c|c|c|c|}
\hline \multirow[b]{2}{*}{$\begin{array}{l}\text { Performance } \\
\text { Category }\end{array}$} & \multirow[b]{2}{*}{ Characteristics } & \multirow[t]{2}{*}{ [26] } & \multirow[t]{2}{*}{ [27] } & \multirow{2}{*}{$\begin{array}{r}{[28]} \\
\text { WPO }\end{array}$} & \multirow[t]{2}{*}{ [29] } & \multirow[t]{2}{*}{ [30] } & \multicolumn{3}{|c|}{ This Study } \\
\hline & & & & & & & $\mathrm{WPO}+\mathrm{Al}_{2} \mathrm{O}_{3}-\mathrm{SiO}_{4}$ & $\begin{array}{c}\mathrm{WPO}+\mathrm{Al}_{2} \mathrm{O}_{3}-\mathrm{SiO}_{4}+10 \% \\
\mathrm{EGR}\end{array}$ & $\begin{array}{c}\mathrm{WPO}+\mathrm{Al}_{2} \mathrm{O}_{3}-\mathrm{SiO}_{4}+20 \% \\
\mathrm{EGR}\end{array}$ \\
\hline & BTE & $27.4 \%$ & $28.4 \%$ & $29.3 \%$ & $26.4 \%$ & $25.4 \%$ & $24 \%$ & $29.6 \%$ & $31 \%$ \\
\hline Energy & BSFC & - & 7.92 MJ/kW-h & $10.08 \mathrm{MJ} / \mathrm{kW}-\mathrm{h}$ & $10.008 \mathrm{MJ} / \mathrm{kW}-\mathrm{h}$ & 11.16 MJ/kW-h & $20 \mathrm{MJ} / \mathrm{kW}-\mathrm{h}$ & $11.76 \mathrm{MJ} / \mathrm{kW}-\mathrm{h}$ & $11.04 \mathrm{MJ} / \mathrm{kW}-\mathrm{h}$ \\
\hline \multirow{2}{*}{ Combustion } & Cylinder pressure & 71 bar & 75.33 bar & 76 bar & 75 bar & 77 bar & 52 bar & 70 bar & 75 bar \\
\hline & HRR & - & $64.31 \mathrm{~J} /{ }^{\circ} \mathrm{CA}$ & $65.41 \mathrm{~J} /{ }^{\circ} \mathrm{CA}$ & $66.81 \mathrm{~J} /{ }^{\circ} \mathrm{CA}$ & $66.15 \mathrm{~J} /{ }^{\circ} \mathrm{CA}$ & $108 \mathrm{~J} /{ }^{\circ} \mathrm{CA}$ & $97 \mathrm{~J} /{ }^{\circ} \mathrm{CA}$ & $99 \mathrm{~J} /{ }^{\circ} \mathrm{CA}$ \\
\hline \multirow{3}{*}{ Emission } & $\mathrm{CO}$ & $18.51 \mathrm{~g} / \mathrm{kW}-\mathrm{h}$ & - & $17.71 \mathrm{~g} / \mathrm{kW}-\mathrm{h}$ & $16.45 \mathrm{~g} / \mathrm{kW}-\mathrm{h}$ & $16.81 \mathrm{~g} / \mathrm{kW}-\mathrm{h}$ & $2.5 \mathrm{~g} / \mathrm{kW}-\mathrm{h}$ & $3.5 \mathrm{~g} / \mathrm{kW}-\mathrm{h}$ & $3.9 \mathrm{~g} / \mathrm{kW}-\mathrm{h}$ \\
\hline & $\mathrm{NO}_{\mathrm{x}}$ & $14.68 \mathrm{~g} / \mathrm{kW}-\mathrm{h}$ & - & $13.65 \mathrm{~g} / \mathrm{Kw}-\mathrm{hr}$ & $13.88 \mathrm{~g} / \mathrm{kW}-\mathrm{h}$ & $15.88 \mathrm{~g} / \mathrm{kW}-\mathrm{h}$ & $16 \mathrm{~g} / \mathrm{kW}-\mathrm{h}$ & $8.4 \mathrm{~g} / \mathrm{kW}-\mathrm{h}$ & $9.5 \mathrm{~g} / \mathrm{kW}-\mathrm{h}$ \\
\hline & $\mathrm{HC}$ & - & - & - & - & - & $0.8 \mathrm{~g} / \mathrm{kW}-\mathrm{h}$ & $0.46 \mathrm{~g} / \mathrm{kW}-\mathrm{h}$ & $0.49 \mathrm{~g} / \mathrm{kW}-\mathrm{h}$ \\
\hline
\end{tabular}

Table 4. Comparison of the results with existing literature works other fuels.

\begin{tabular}{|c|c|c|c|c|c|c|c|c|c|c|c|}
\hline \multirow{2}{*}{ Performance Category } & \multirow[b]{2}{*}{ Characteristics } & [31] & [32] & [33] & [34] & [35] & [36] & \multicolumn{4}{|c|}{ This Study } \\
\hline & & $a^{a}$ & $\mathrm{~b}$ & c & $\mathrm{d}$ & e & $\mathrm{f}$ & Diesel $\mathrm{g}$ & $\mathrm{WPO}+\mathrm{Al}_{2} \mathrm{O}_{3}-\mathrm{SiO}_{4}$ & $\mathrm{WPO}+\mathrm{Al}_{2} \mathrm{O}_{3}-\mathrm{SiO}_{4}+10 \% \mathrm{EGR}$ & $\mathrm{WPO}+\mathrm{Al}_{2} \mathrm{O}_{3}-\mathrm{SiO}_{4}+20 \% \mathrm{EGR}$ \\
\hline \multirow{2}{*}{ Energy } & BTE & $34.45 \%$ & $34.93 \%$ & $33.23 \%$ & $32.33 \%$ & $30.33 \%$ & $28.82 \%$ & $27.3 \%$ & $24 \%$ & $29.6 \%$ & $31 \%$ \\
\hline & BSFC & $14 \mathrm{MJ} / \mathrm{kW}-\mathrm{h}$ & $21 \mathrm{MJ} / \mathrm{kW}-\mathrm{h}$ & $17.5 \mathrm{MJ} / \mathrm{kW}-\mathrm{h}$ & $14.6 \mathrm{MJ} / \mathrm{kW}-\mathrm{h}$ & $\begin{array}{l}10.56-10.84 \\
\mathrm{MJ} / \mathrm{kW}-\mathrm{h}\end{array}$ & $18.5 \mathrm{MJ} / \mathrm{kW}-\mathrm{h}$ & $16 \mathrm{MJ} / \mathrm{kW}-\mathrm{h}$ & $20 \mathrm{MJ} / \mathrm{kW}-\mathrm{h}$ & $11.76 \mathrm{MJ} / \mathrm{kW}-\mathrm{h}$ & $11.04 \mathrm{MJ} / \mathrm{kW}-\mathrm{h}$ \\
\hline \multirow{3}{*}{ Combustion } & Cylinder pressure & $79.65 \mathrm{bar}$ & $81.32 \mathrm{bar}$ & $80.25 \mathrm{bar}$ & $79.55 \mathrm{bar}$ & $75.75 \mathrm{bar}$ & 72 bar & $68 \mathrm{bar}$ & $52 \mathrm{bar}$ & $70 \mathrm{bar}$ & $75 \mathrm{bar}$ \\
\hline & Delay period & $16.5^{\circ} \mathrm{CA}$ & $17^{\circ} \mathrm{CA}$ & $18^{\circ} \mathrm{CA}$ & $16^{\circ} \mathrm{CA}$ & $20^{\circ} \mathrm{CA}$ & $21^{\circ} \mathrm{CA}$ & - & - & - & - \\
\hline & EGT/HRR & $310-325^{\circ} \mathrm{C}$ & $340-345^{\circ} \mathrm{C}$ & $335-342{ }^{\circ} \mathrm{C}$ & $355-360^{\circ} \mathrm{C}$ & $365-375^{\circ} \mathrm{C}$ & $350-363^{\circ} \mathrm{C}$ & $80 \mathrm{~J} /{ }^{\circ} \mathrm{CA}$ & $108 \mathrm{~J} /{ }^{\circ} \mathrm{CA}$ & $97 \mathrm{~J} /{ }^{\circ} \mathrm{CA}$ & $99 \mathrm{~J} /{ }^{\circ} \mathrm{CA}$ \\
\hline \multirow{2}{*}{ Emission } & со & $3.2 \mathrm{~g} / \mathrm{kW}-\mathrm{h}$ & $2.75 \mathrm{~g} / \mathrm{kW}-\mathrm{h}$ & $3.2 \mathrm{~g} / \mathrm{kW}-\mathrm{h}$ & $4.9 \mathrm{~g} / \mathrm{kW}-\mathrm{h}$ & $2.5-2.9 \mathrm{~g} / \mathrm{kW}-\mathrm{h}$ & $5.2 \mathrm{~g} / \mathrm{kW}-\mathrm{h}$ & $4.2 \mathrm{~g} / \mathrm{kW}-\mathrm{h}$ & $2.5 \mathrm{~g} / \mathrm{kW}-\mathrm{h}$ & $3.5 \mathrm{~g} / \mathrm{kW}-\mathrm{h}$ & $3.9 \mathrm{~g} / \mathrm{kW}-\mathrm{h}$ \\
\hline & $\mathrm{NO}_{\mathrm{x}}$ & $13 \mathrm{~g} / \mathrm{kW}-\mathrm{h}$ & $15 \mathrm{~g} / \mathrm{kW}-\mathrm{h}$ & $25.05 \mathrm{~g} / \mathrm{kW}-\mathrm{h}$ & $11.32 \mathrm{~g} / \mathrm{kW}-\mathrm{h}$ & $7.4-8.5 \mathrm{~g} / \mathrm{kW}-\mathrm{h}$ & $25.05 \mathrm{~g} / \mathrm{kW}-\mathrm{h}$ & $14 \mathrm{~g} / \mathrm{kW}-\mathrm{h}$ & $16 \mathrm{~g} / \mathrm{kW}-\mathrm{h}$ & $8.4 \mathrm{~g} / \mathrm{kW}-\mathrm{h}$ & $9.5 \mathrm{~g} / \mathrm{kW}-\mathrm{h}$ \\
\hline
\end{tabular}

${ }^{a}$ Dual biodiesel blends. ${ }^{\mathbf{b}}$ Nano-catalyst-coated pistons. ${ }^{\mathbf{c}}$ Mullite and aluminium titanate as thermal barrier coating. ${ }^{\mathbf{d}}$ Titanium oxide and aluminum oxide alloy-coated piston fueled with biofuel made up of agricultural waste. ${ }^{\mathbf{e}} \mathrm{Al}_{2} \mathrm{O}_{3}$ nano-ceramic material/ rice bran and pongamia methyl ester. ${ }^{\mathbf{f}}$ Nerium biodiesel and its blends. ${ }^{\mathrm{g}}$ Standard diesel. 
The comparative results from Table 4 with other fuels showed that most of the indicators for $\mathrm{WPO}+\mathrm{Al}_{2} \mathrm{O}_{3}-\mathrm{SiO}_{4}$ are slightly lower when compared to diesel fuel and other fuels presented in the literature. However, the $\mathrm{WPO}+\mathrm{Al}_{2} \mathrm{O}_{3}-\mathrm{SiO}_{4}+10 \%$ or $20 \% \mathrm{EGR}$ have more or less comparable results with the literature. Coming to the nano-coating materials, $\mathrm{Al}_{2} \mathrm{O}_{3}$ $\mathrm{SiO}_{4}$ has shown significant improvements when compared to only $\mathrm{Al}_{2} \mathrm{O}_{3}$ nano-coating results. However, $\mathrm{Al}_{2} \mathrm{O}_{3}-\mathrm{SiO}_{4}$ has slightly lower performance when compared to materials such as titanium oxide and aluminium oxide alloy, mullite and aluminium titanate coating and the nano-catalyst.

\section{Conclusions}

An experimental investigation was carried out to analyze and understand the energy, combustion, and emission characteristics of CI engines whose combustion chambers are coated with $\mathrm{Al}_{2} \mathrm{O}_{3}-\mathrm{SiO}_{4}$ and fueled with WPO derived from the pyrolysis of waste plastics and blends of WPO and EGR. The tests were performed on a CI engine under different fuel use scenarios (diesel, WPO, WPO + EGR). The EGR ratio with WPO was varied from 0-20\%. Based on the experimental investigation, conclusions were drawn.

- $\quad$ The CI engine operated steadily on WPO and the combined approach of WPO and EGR even at maximum brake power loads;

- $\quad$ The use of $\mathrm{WPO}+\mathrm{Al}_{2} \mathrm{O}_{3}-\mathrm{SiO}_{4}$ over the standard diesel fuel in $\mathrm{CI}$ engines reduced the $\mathrm{CO}$ and $\mathrm{HC}$ emissions by $\sim 50 \%$ and $\sim 22 \%$, respectively; however, the $\mathrm{NO}_{\mathrm{x}}$ emissions increased by $13 \%$. Additionally, the BTE was reduced by $12.86 \%$, clearly suggesting that WPO alone cannot be used as fuel;

- The EGR mixture in the WPO resulted in variations in energy, combustion, and emission characteristics, suggesting that higher rates of EGR would result in high amounts of emissions compared to lower EGR or intermediate rates;

- The increases in $\mathrm{NO}_{X}$ and $\mathrm{CO}$ emissions are mild when $\mathrm{WPO}+\mathrm{Al}_{2} \mathrm{O}_{3}-\mathrm{SiO}_{4}+10 \%$ EGR is used over the $\mathrm{WPO}+\mathrm{Al}_{2} \mathrm{O}_{3}-\mathrm{SiO}_{4}$.

Overall, the results show that WPO combined with $10 \%$ EGR could be a potential fuel for future $\mathrm{CI}$ engines whose combustion chambers are coated with $\mathrm{Al}_{2} \mathrm{O}_{3}-\mathrm{SiO}_{4}$.

Author Contributions: Conceptualization, P.S. and N.M.K.; methodology, P.S. and N.M.K.; formal analysis, P.S. and N.M.K.; investigation, P.S., M.E. and N.M.K.; resources, P.S., M.E. and N.M.K.; data curation, P.S. and N.E.; writing-original draft preparation, P.S. and N.M.K.; writing-review and editing, N.M.K.; visualization, P.S. and N.M.K. All authors have read and agreed to the published version of the manuscript.

Funding: This research received no external funding.

Institutional Review Board Statement: Not applicable.

Informed Consent Statement: Not applicable.

Data Availability Statement: Not applicable.

Acknowledgments: The authors would like to acknowledge the technical support from SusSo Foundation Cares, a Non-profitable Organization (NPO), India.

Conflicts of Interest: The authors declare no conflict of interest.

\section{References}

1. British Petroleum (BP). Primary Energy. 2020. Available online: https://www.bp.com/en/global/corporate/energy-economics/ statistical-review-of-world-energy/primary-energy.html (accessed on 29 December 2021).

2. Vieira, S. Pros and Cons of 10 Types of Energy. 2020. Available online: https://www.aje.com/arc/energy-types-pros-cons / (accessed on 29 December 2021).

3. UN; ESCAP. Energy Security and Sustainable Development in Asia and the Pacific; ESCAP Publications: Bangkok, Thailand, 2008; p. 216. ISBN $9211205441 / 9789211205442$.

4. Ritchie, H.; Roser, M. $\mathrm{CO}_{2}$ and Greenhouse Gas Emissions. Our World Data. 2020. Available online: https:/ / ourworldindata.org/ co2-and-other-greenhouse-gas-emissions (accessed on 29 December 2021). 
5. Gielen, D.; Gorini, R.; Wagner, N.; Leme, R.; Gutierrez, L.; Prakash, G.; Renner, M. Global Energy Transformation: A Roadmap to 2050. International Renewable Energy Agency. 2019. Available online: https://www.irena.org/publications/2019/Apr/Globalenergy-transformation-A-roadmap-to-2050-2019Edition (accessed on 29 December 2021).

6. Elavarasan, R.M.; Shafiullah, G.M.; Padmanaban, S.; Kumar, N.M.; Annam, A.; Vetrichelvan, A.M.; Holm-Nielsen, J.B. A comprehensive review on renewable energy development, challenges, and policies of leading Indian states with an international perspective. IEEE Access 2020, 8, 74432-74457. [CrossRef]

7. Koutsoyiannis, D. The unavoidable uncertainty of renewable energy and its management. In Proceedings of the EGU General Assembly Conference, Vienna, Austria, 17-22 April 2016; p. EPSC2016-18430.

8. Jezard, A. Fossil Fuels Will Still Dominate Energy in 20 Years Despite Green Power Rising. World Economic Forum. 2017. Available online: https://www.weforum.org/agenda/2017/10/fossil-fuels-will-dominate-energy-in-2040/ (accessed on 29 December 2021).

9. D'Adamo, I.; Gastaldi, M.; Morone, P.; Rosa, P.; Sassanelli, C.; Settembre-Blundo, D.; Shen, Y. Bioeconomy of sustainability: Drivers, opportunities and policy implications. Sustainability 2022, 14, 200. [CrossRef]

10. Ikram, M.; Sroufe, R.; Awan, U.; Abid, N. Enabling Progress in Developing Economies: A Novel Hybrid Decision-Making Model for Green Technology Planning. Sustainability 2022, 14, 258. [CrossRef]

11. D’Amico, G.; Szopik-Depczyńska, K.; Beltramo, R.; D’Adamo, I.; Ioppolo, G. Smart and Sustainable Bioeconomy Platform: A New Approach towards Sustainability. Sustainability 2022, 14, 466. [CrossRef]

12. Ma'arof, N.A.N.B.; Hindryawati, N.; Khazaai, S.N.M.; Bhuyar, P.; Rahim, M.H.A.; Maniam, G.P. Biodiesel (Methyl Esters). Maejo Int. J. Energy Environ. Commun. 2021, 3, 30-43.

13. Embong, N.H.; Hindryawati, N.; Bhuyar, P.; Govindan, N.; Rahim, M.H.A.; Maniam, G.P. Enhanced biodiesel production via esterification of palm fatty acid distillate (PFAD) using rice husk ash $\left(\mathrm{NiSO}_{4}\right) / \mathrm{SiO}_{2}$ catalyst. Appl. Nanosci. 2021, 1-9. [CrossRef]

14. Khazaai, S.N.M.; Bhuyar, P.; Rahim, M.H.A.; Alwi, M.H.F.M.; Yiting, S.; Maniam, G.P. Rapid determination of diesel/biodiesel blend ratio using refractive index, density, and kinematic viscosity measurements. Biomass Convers. Biorefin. 2021, 1-7. [CrossRef]

15. Zheng, Q.P.; Li, S.; Lang, X.J.; Zhang, K.P. Simulation and Experimental Study on Turbocharged Inter-Cooled Diesel Engine with Exhaust Gas Recirculation. Chin. Intern. Combust. Engine Eng. 2012, 33, 33-37.

16. Anantha Raman, L.; Rajakumar, S.; Deepanraj, B.; Lokesh, P. Study on performance and emission characteristics of a single cylinder diesel engine using exhaust gas recirculation. Therm. Sci. 2017, 21, s435-s441. [CrossRef]

17. Saravanan, P.; Kumar, N.M.; Ettappan, M.; Dhanagopal, R.; Vishnupriyan, J. Effect of exhaust gas recirculation o performance, emission and combustion characteristics of ethanol-fueled diesel engine. Case Stud. Therm. Eng. 2020, 20, 100643. [CrossRef]

18. Yuan, X.; Kumar, N.M.; Brigljević, B.; Li, S.; Deng, S.; Byun, M.; Ok, Y.S. Sustainability-inspired upcycling of waste polyethylene terephthalate plastic into porous carbon for $\mathrm{CO}_{2}$ capture. Green Chem, 2022; Advance Article. [CrossRef]

19. Taymaz, I.; Cakir, K.; Gur, M.; Mimaroglu, A. Experimental investigation of heat losses in a ceramic coated diesel engine. Surf. Coat. Technol. 2003, 169, 168-170. [CrossRef]

20. $\mathrm{Wu}, \mathrm{X}$.J. The crack number density theory on air-plasma-sprayed thermal barrier coating. Surf. Coat. Technol. 2019, 358, 347-352. [CrossRef]

21. Balu, P.; Saravanan, P.; Jayaseelan, V. Effect of ceramic coating on the performance, emission, and combustion characteristics of ethanol DI diesel engine. Mater. Today Proc. 2021, 39, 1259-1264. [CrossRef]

22. Mani, M.; Nagarajan, G.; Sampath, S. An experimental investigation on a DI diesel engine using waste plastic oil with exhaust gas recirculation. Fuel 2010, 8, 1826-1832. [CrossRef]

23. Paranthaman, S.; Dharmalingam, M.; Arockiaraj, G.A.; Venkatraman, V. An experimental investigation on a low heat rejection diesel engine using waste plastic oil with different injection timing. Therm. Sci. 2020, 24 Pt B, 453-461. [CrossRef]

24. Saravanan, P.; Mala, D. Performance, Emission and Combustion Characteristics of Low Heat Rejection Diesel Engine Operated by Waste Plastic Oil and Diesel Fuel Blends. J. Balk. Tribol. Assoc. 2020, 26, 416-427.

25. Saravanan, P.; Mala, D.; Jayaseelan, V.; Kumar, N.M. Experimental performance investigation of Partially Stabilized Zirconia coated low heat rejection diesel engine with waste plastic oil as a fuel. Energy Sources Part A Recovery Util. Environ. Eff. 2019, 1-14. [CrossRef]

26. Mani, M.; Subash, C.; Nagarajan, G. Performance, emission and combustion characteristics of a DI diesel engine using waste plastic oil. Appl. Therm. Eng. 2009, 29, 2738-2744. [CrossRef]

27. Venkatesan, H.; Sivamani, S.; Bhutoria, K.; Vora, H.H. Experimental study on combustion and performance characteristics in a DI CI engine fuelled with blends of waste plastic oil. Alex. Eng. J. 2018, 57, 2257-2263. [CrossRef]

28. Kaimal, V.K.; Vijayabalan, P. A detailed study of combustion characteristics of a DI diesel engine using waste plastic oil and its blends. Energy Convers. Manag. 2015, 105, 951-956. [CrossRef]

29. Das, A.K.; Hansdah, D.; Mohapatra, A.K.; Panda, A.K. Energy, exergy and emission analysis on a DI single cylinder diesel engine using pyrolytic waste plastic oil diesel blend. J. Energy Inst. 2020, 93, 1624-1633. [CrossRef]

30. Devaraj, J.; Robinson, Y.; Ganapathi, P. Experimental investigation of performance, emission and combustion characteristics of waste plastic pyrolysis oil blended with diethyl ether used as fuel for diesel engine. Energy 2015, 85, 304-309. [CrossRef]

31. Srithar, K.; Arun Balasubramanian, K.; Vivar, M.; Skryabin, I. An experimental investigation on diesel and low heat rejection engines with dual biodiesel blends. Int. J. Green Energy 2013, 10, 1041-1055. [CrossRef] 
32. Ramalingam, S.; Rajendran, S.; Ganesan, P. Performance improvement and emission control in a direct injection diesel engine using nano catalyst coated pistons. Biofuels 2016, 7, 529-535. [CrossRef]

33. Nandeeswaran, S.; Sriram, K. Experimental Investigation on Performance of Single Cylinder Diesel Engine with Mullite and Aluminium Titanate as Thermal Barrier Coating. Int. J. Eng. Res. Technol. 2021, 9, 64-67.

34. Narad, A.M.; Joshi, M.P. Experimental analysis of CI engine using titanium oxide and aluminum oxide alloy coated piston fuelled with biofuel made up of agricultural waste. Results Mater. 2020, 8, 100140. [CrossRef]

35. Musthafa, M.M.; Sivapirakasam, S.P.; Udayakumar, M. A comparative evaluation of $\mathrm{Al}_{2} \mathrm{O}_{3}$ coated low heat rejection diesel engine performance and emission characteristics using fuel as rice bran and pongamia methyl ester. J. Renew. Sustain. Energy 2010, 2, 053105. [CrossRef]

36. Senthil, R.; Sivakumar, E.; Silambarasan, R.; Mohan, G. Performance and emission characteristics of a low heat rejection engine using Nerium biodiesel and its blends. Int. J. Ambient Energy 2017, 38, 186-192. [CrossRef] 